\title{
Olfactory Dysfunction in Covid-19 Patients, The Current Evidence and Literature Review
}

\author{
Ali Almomen*, Zainab Alshuhayb, Hassan Almomen, Ahmed Alnabi, Amirah Aldhurais, Zahra Almoumen, Zainab \\ Ali and Balsam Alawami
}

Department of ENT, King Fahad Specialist Hospital, Saudi Arabia

Submission: August 08, 2020; Published: September 03, 2020

*Corresponding author: Ali Almomen, Senior Consultant, Rhinology \& Skull Base Surgery, Department of Otorhinolaryngology, King Fahad Specialist Hospital Dammam, MOH, Saudi Arabia

Abstract

Background: Osteoma, fibrous, dysplasia and ossifying fibroma are fibro-osseus lesions that can occur in the paranasal sinuses, management of these lesions can be technically challenging due to proximity to the orbit and skull base, with the advancement in endoscopic endonasal surgery and development of technologies such as image guidance can improve the safety of endoscopic removal and improve its safety.

Illustrative cases: Three cases of fibro-ossuoes lesions are presented in this study an adult female with left frontoethmoidal osteoma, an adult male with left ethmoid fibrous dysplasia, both of whom have been treated with pure endonasal endoscopic approach with image guidance, the third case is a male child with juvenile ossifying fibroma, he was treated initially with the endoscopic approach with image guidance, but had a skull base recurrence 6 months later which was removed with an open craniotomy approach.

Conclusion: Image guidance is a valuable tool in improving safety and efficiency of endoscopic sinus surgery particularly in challenging cases such as fibro-osseus lesions with proximity to the skull base and orbit.

Keywords: Image guidance; Osteoma; Endoscopic surgery

\section{Short Communication}

On the $11^{\text {th }}$ of march, 2020, the World Health Organization declared the emergence of a new global pandemic, the corona virus disease 2019 (COVID- 19) [1]. COVID- 19 is a highly infections respiratory disease, caused by SARS- CoV 2, the novel virus severe acute respiratory syndrome corona virus- 2 [2-5]. The first reported case traces back to December 12, 2019 [2]. Since that, the disease became a global phenomenon with $11,669,259$ confirmed case, including 539,906 deaths, reported to WHO as of July 8, 2020 [6].

The disease clinical presentation is quite heterogeneous in nature, ranging from asymptomatic to severe viral pneumonia and acute respiratory failure. In one systematic review analyzing five retrospective clinical studies for a total of 1556 hospitalized patients with COVID-19, the most common symptoms identified were a triad of fever (85.6\%), cough (68.7\%), and fatigue (39.4\%) [7]. Other symptoms can include but not limited to, odynophagia, headache, dizziness, myalgia, dyspnea, and abdominal pain [8].

A fairly large number of anecdotal reports identified olfactory dysfunction as a main symptom, emerging in a relatively significant number of COVID- 19 patients. In a published study on 417 covid patients, $85.6 \%$ of patients reported decreased sense of smell. Of those reporting decreased sense of smell, $79.6 \%$ reported a complete loss [9]. Another study, done on 131, reported a similarly high prevalence of olfactory dysfunction in COVID- 19 patients, in which, more than half patients reported both taste dysfunction and anosmia (72/131, 55.0\%) [8].

Covid 19 patients can exhibit olfactory dysfunction (OD) as a symptom at different points in their disease course. In a cohort by Lechien et al. [9] on 417 COVID- 19 patients, 11.8\% reported OD as the initial symptom. While $22.8 \%$ reported it to be occurring at the same time as other symptoms and $65.4 \%$ as occurring after other COVID-19 symptoms. Another cohort conducted on 237 patients, noted anosmia in $73 \%$ of the patients prior to covid diagnosis, with its being the initial symptom in $26.6 \%$ [10].

The exact mechanism of olfactory dysfunction in COVID- 19 is still largely a matter of speculations. Since most patients with anosmia do not report accompanying nasal obstruction or other rhinitis symptoms, it is proposed that anosmia is most probably 
caused by direct damage of the virus to the olfactory receptors in the neuroepithelium [11]. Direct invasion of the olfactory nerve by SARS-CoV-2 can be supported by earlier studies conducted during the pandemic of SARS-CoV in 2002-2003. In those studies, viral particles were exclusively isolated from the central nervous system [12]. Since the main viral entry is through the binding to ACE2 receptors, which are expressed in the olfactory and gustatory cells, anosmia can be the result of direct damage to such cells [13].

Since there is no long term follow up data is available, it is too early at this point to determine if and when full recovery of olfactory function happen in COVID- 19 patients, Initial reports indicate that full recovery is possible. In a prospective clinical series of 78 patients, $50 \%$ of patients remained anosmic at 15 days and $24 \%$ had recovered a normal sense of smell [14]. Another study conducted on 131 covid patients, among the 77 anosmic patients, total recovery occurred in $40.3 \%$ of cases $(n=31)$ and smell problems remained in 59.7\% $(n=46)$ [8].

Currently, the World Health Organization have not recognized anosmia to be a screening symptom. As the battle against this pandemic continues, we urge the respected authorities to consider olfactory dysfunction as a main screening symptom and regard any subject presenting with new onset sudden anosmia to be COVID- 19 positive until proven otherwise..

\section{References}

1. World Health Organization (2020) WHO director-general's opening remarks at the media briefing on COVID-19.

2. Zhou P, Yang X L, Wang X G, Ben Hu, Lei Zhang, et al. (2020) A pneumonia outbreak associated with a new coronavirus of probable bat origin. Nature 579: 270-273.
3. Wu F, Zhao S, Yu B, Yan Mei Chen, Wen Wang, et al. (2020) A new coronavirus associated with human respiratory disease in China. Nature 579(7798): 265-269.

4. Wang D, Hu B, Hu C, Fangfang Zhu, Xing Liu, et al. (2020) Clinical characteristics of 138 hospitalized patients with 2019 novel coronavirus-infected pneumonia in Wuhan, China. JAMA 323(11): 1061-1069.

5. Huang C, Wang Y, Li X, Lili Ren, Jianping Zhao, et al. (2020) Clinical features of patients infected with 2019 novel coronavirus in Wuhan, China. Lancet. 395(10223): 497-506.

6. WHO Coronavirus Disease (COVID-19) Dashboard.

7. Lovato A, de Filippis C (2020) Clinical Presentation of COVID-19: A Systematic Review Focusing on Upper Airway Symptoms. Ear, Nose \& Throat J 13.

8. Abalo Lojo J, Pouso Diz J, Gonzalez F (2020) Taste and Smell Dysfunction in COVID-19 Patients. Ann Otol Rhinol Laryngol 129(10): 1041-1042.

9. Lechien JR, Chiesa Estomba CM, De Siati DR, et al. (2020) Olfactory and gustatory dysfunctions as a clinical presentation of mild-to-moderate forms of the coronavirus disease (COVID- 19): a multicenter European study. Eur Arch Otorhinolaryngol 277(8): 2251-2261.

10. Kaye R, Chang C, Kazahaya K, Brereton J, Denneny J (2020) COVID-19 Anosmia Reporting Tool: Initial Findings. Otolaryngol Head Neck Surg 163(1): 132-134.

11. Vaira L, Salzano G, Deiana G, De Riu G (2020) Anosmia and Ageusia: Common Findings in COVID-19 Patients. Laryngoscope 1.

12. Xu J, Zhong S, Liu J, Li Li, Yong Li, et al. (2005) Detection of severe acute respira- tory syndrome coronavirus in the brain: potential role of the chemokine mig in pathogenesis. Clin Infect Dis 41(8): 1089-1096.

13. Xu H, Zhong L, Deng J, Jiakuan Peng, Hongxia Dan, et al. (2020) High expression of ACE2 receptor of 2019-nCoV on the epithelial cells of oral mucosa. Int J Oral Sci 12(1): 8.

14. Lechien J, Barillari M, Jouffe L, Saussez S (2020) Anosmia Is a Key Symptom of COVID-19 Infection and Should Be Used as a Diagnostic Tool. Ear, Nose \& Throat J.

\section{Your next submission with Juniper Publishers will reach you the below assets}

- Quality Editorial service

- Swift Peer Review

- Reprints availability

- E-prints Service

- Manuscript Podcast for convenient understanding

- Global attainment for your research

- Manuscript accessibility in different formats

( Pdf, E-pub, Full Text, Audio)

- Unceasing customer service

Track the below URL for one-step submission https://juniperpublishers.com/online-submission.php 